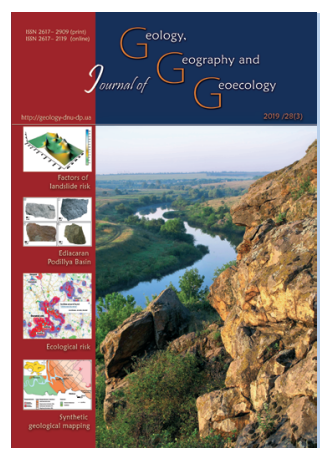

Journal of Geology.

ISSN 2617-2909 (print)

Geography and

Geoecology

ISSN 2617-2119 (online)

Mishchenko O.

Journal home page: geology-dnu-dp.ua

Journ.Geol.Geograph.

Geology,

28(3), 487-494.

doi: $10.15421 / 111944$

\title{
Structural organization of sacred landscapes
}

\section{O. Mishchenko}

Lesya Ukrainka Eastern European National University, Lutsk, Ukraine, mischenko.olena@eenu.edu.ua

Received: 30.01 .2019

Received in revised form: 11.02 .2019

Accepted: 30.06.2019
Journ. Geol. Geograph. Geoecology, 28(3), 487-494.

and the humanitarian sciences. The system approach to the study of sacred landscapes as a holistic organized territorial structure and a set of methods is used in this work, in particular: structural and logical generalization and system analysis, comparative and geographical, historical and geographical. The author considers the significance of the notion of sacral landscape as being broader than religion per se, and considers it a natural, natural-anthropogenic and anthropogenic system associated with certain symbols of life, myths, significant events, and, indeed, religious feelings that are of great importance to a person or group of people and requires special respect and protection. The structural organization of all sacred landscapes is characterized by their properties and spatial structure and is closely connected with their social and functional purpose. As a result, such territorial systems can be divided into: confessional, taphal, active, abnormal. The sacred landscape is characterized by polystructurality, that is, the presence of spatial, temporal and morphological structure. In the spatial structure of the sacral landscape, the following components can be distinguished: the sacred object, anthropogenic and technogenic component, the landscape structure and a person with his/ her spiritual experience. In addition, such a structure has a hierarchical construction, where individual, local, regional, national and global levels can be distinguished. This article presents the peculiarities of the temporal structure of sacral landscapes and outlines the external, internal, and the functioning time. Particular attention is paid to the characteristic of internal time, where one can distinguish the following phases of development: the formation of a natural, natural-anthropogenic or anthropogenic landscape; the creation of a spiritual component; loss of sacred human perception of a natural, natural-anthropogenic or anthropogenic landscape; the disappearance of the natural or natural- anthropogenic landscape. Taking into account the morphological structure of the sacred landscape, it is substantiated that religious objects serving as markers of sacred landscapes cannot correspond to one or another morphological unit of the landscape, that is, completely repeat its outlines and boundaries. However, there is a correlation between the type of landscape and the features of the sacred objects that were formed there.

Keywords: sacred landscape, sacred object, structure, structural organization of the landscape.

\section{Структурна організація сакральних ландшафтів}

\section{О. Міщенко}

Східноєвропейський національний університет імені Лесі Украӥнки, Луцььк, Україна, mischenko.olena@eепи.еdи.иа

Анотація. В статті розглянуто зміст поняття структурна організація в контексті вивчення сакральних ландшафтів, а також розширено понятійне поле дефініції «сакральний ландшафт», що сприяє узагальненню поглядів представників різних наукових шкіл, які досліджували категорію “сакральний”. Сакральний ландшафт розглядається з позицій маркованої географічної системи, яка сформована духовним досвідом людини, який за своєю суттю є ширшим ніж релігійний досвід. Структурна організація усіх сакральних ландшафтів має різне суспільно-функціональним призначенням, тому й відрізняється просторовою структурою. Відповідно такі територіальні системи можна поділити на: конфесійні, тафальні, діяльнісні, аномальні. В межах сакрального ландшафту виявлено й охарактеризовано просторову, часову, морфологічну структури. 3'ясовано, що просторова структура досліджуваних територіальних систем має ієрархічну будову, де можна виокремити індивідуальний, локальний, регіональний, національний, глобальні рівні й поділяється на такі складові: сакральний об'єкт, антропогеннотехногенна складова, ландшафтна структура, людина з іiї духовним досвідом. Обгрунтовано особливості часової структури сакральних ландшафтів й виокремлено зовнішній, внутрішній та час функціонування. Автором доведено, що культові об'єкти, 
які слугують маркерами сакрального ландшафту не можуть відповідати тій чи іншій морфологічній одиниці ландшафту, тобто повністю повторювати їі контури та межі. Проте, існує взаємозалежність між типом ландшафтної місцевості і особливостями сформованого в її межах сакрального об’єкту.

Ключові слова: сакральний ландшафт, сакральний об'єкт, структура, структурна організація ландшафту.

Introduction. A sacred landscape has signs of a complex system characterized by a territorial organization, polystructurality, nonlinear interaction of components and spatial heterogeneity.

The complexity of landscapes should be distinguished from landscape heterogeneity: complexity is a state of orderliness and chaos with wellseparated structures (Papadimitriou, 2010). Therefore, in geographic science, the random distribution model of spatial elements is used to assess the complexity of the logical spatial organization of real landscapes (Cushman et al., 2012; Turner, Gardner, 2015).

The founder of the scientific study of the phenomenon of "organization" can be considered A. Bogdanov (1925), who elaborated the complete idea of organizational science, formulated its main principles and laws, explained the mechanisms of manifestation, presented the role of science in the organization and its significance in the understanding of the universe, and outlined ways of its development.

Problems and questions of the organization of natural and socio-economic systems are covered in the works of A. Topchiev (1988), L. Leskov (2005), B. Mil'ner (2005). Among landscape experts it is necessary to distinguish the work of V. Preobrazhenskij (1986) "Organization, organization of the landscape".

The structural organization of territorial systems is an ordered distribution of their components in general, a means of their interconnection, cosubordination, the nature of the hierarchy (Petlin, 2016).

The structural organization of the landscape serves as an indicator of landscape-forming processes. It is the totality of the structures of the landscape, and the corresponding links characterize the territorial system, their functional purpose and organizational capabilities.

The sacred landscape is considered by us as a natural, natural-anthropogenic, anthropogenic system, associated with certain life symbols, myths, important events, religious feelings, is extremely valuable to a person or group of people and needs special respect and protection (Mishchenko, 2018).

Sacred landscape is an extremely interesting and relevant research object, which includes in its composition territorial systems of different genesis, a person, his/her spiritual perception of these systems. The need to identify the types of structures of the sacred landscape and their characteristics, which determines the degree of its complexity and organization, led to the choice of the topic of scientific work.

Materials and methods. The methodological basis of the study is the concept of constructive-geographic analysis, which is based on the approaches of the natural sciences and the humanities. The paper uses a systematic approach to the study of sacred landscapes as a holistic organized territorial system and a set of methods, in particular:

- structural and logical generalization and system analysis, which are used for study and generalization of theoretical approaches to the definition of concepts of structure, structural organization of territorial systems;

- comparative and geographical, which was used for the purpose of determining the morphological structures of sacred landscapes in the conditions of the Volyn Polissya;

- historical and geographical, which was used to study the historical and geographical features of the formation of sacred landscapes.

Results and their analysis. A structure is a description of the composition and a spatial picture of the composition of an object, matter, the interplacement of formations, parts, details, elements, a certain functional interconnection of the components of the object, and the internal structure (Velykyi tlumachnyi slovnyk suchasnoi ukrainskoi movy, 2005). The structure contains the composition of subordinate systems, their mutual arrangement (spatial, or morphological structure) and the various interactions between them (functional structure), all in dynamics, variability, and space and time (Mazing, 1973); structure is a generalized characteristic of specific system properties that captures the elements, relations, system connections, and their organization in an abstract form (Sadovskij, 1974).

Any geographical construct is structured according to a particular structural scheme. The simplest such scheme is the conditional graphic (mathematical, etc.) of the elements of the system and the links between them (Nechiporenko, 1977). The structure of a natural and territorial system is considered as a changeable system order in the form of an invariant entity of the organization, which consists of mechanisms of its spatio-temporal functioning, internal components and internally emergent 
components as a manifestation of integrity (Petlin, 2006). Spatially complex combinations of indigenous and conventionally indigenous components with derivatives created by man as components of the environment as anthropogenized structure are considered (Ivanov, 2007).

The scheme of classification of structures of the geographical system distinguishes the following main types:

- spatial, in particular vertical (topical), territorial (choral);

- time, in particular, functional and ethological (Samoilenko, 2003).

The configuration of a sacred landscape has a spotted structure and the background of it is landscape complexes with the usual sacred level and "the nuclei" are the places with an increased number of foci (especially sacred) (Hrodzynskyi, 2005). In the case of ethnocultural analysis of sacral landscapes, the spotted structure will be multilayered, where "nuclei" may overlap (sometimes completely) or not at all. For each ethnic group inhabiting the corresponding ethno-cultural landscape, sacral nuclei will be different places or objects. Moreover, the Ukrainian sacred landscape will be profane for the Jewish or Polish ethnos (Volovyk, 2013; Denysyk, 2014). Volovyk (2013) has built a sacred landscape model for a monoethnic and polyethnic landscape. Such a model corresponds to the idea of "sacred centroperiphery", where in the landscape live the community, subordinated to the one true God with the corresponding unique sacral order (Kizima, 2003). However, the sacred landscape encompasses not only religious systems (Mishchenko, 2018). Since the process of sacralization is conditioned by the provision of natural, natural and anthropogenic objects with unusual properties (sacred content), the sacred landscape is interpreted as a symbolically marked geographical system, formed by the spiritual experience of a person, which in its essence is wider than religious experience alone.

The structural organization of any sacral landscape is characterized by its properties and spatial structure and is closely connected with their social and functional purpose. Accordingly, such territorial systems can be divided into: confessional, which are related with the peculiarities of religious belief within a certain religious doctrine; burial;

- taphal, which are modern and ancient places of

- active, which are territorial systems, connected with a certain event, which is important, sacred, religious curative, meaningful;
- abnormal, which are territorial systems of sacredness, the special significance of which are manifested through deviations from the norm or from the average value of physico-geographical, biogeochemical or other indicators.

Undoubtedly, in practice, the same sacred landscapes can have different functional purposes. For example, a number of sacred springs which are located within the Volyn region are sanctified by representatives of Christian institutions. In addition, such objects may be associated with a particular event: the appearance of a "miracle" (church objects, or saints), healing from an illness. The water in the springs has somewhat abnormal characteristics: low temperature values, high transparency, high content of silver.

N. Lavrinova (2015) has constructed a systemic model of a geographic landscape, in the structure of which are allocated natural and geocultural subsystems. The sacred landscape in this model serves as an inalienable part of integrating the subsystems into a single geospatial space. The history of the formation of the selected elements in this model is divided into periods that can be considered as structural parts of the sacred landscape, in particular:

- formation of a natural basis;

- formation of ethnic basis;

- the creation of cultural complexes, which are elements of the superstructure that define and characterize the cultural content of the territorial system. The ingredients of such complexes are ideology, politics, religion, culture, actions, customs, feelings.

The sacred landscape is a complex system in which not only the natural and anthropogenic components, but also the spiritual, interact. This entails the transfer of the national heritage from generation to generation of the, that is, objects of cultural heritage that can have a natural, natural- anthropogenic or anthropogenic origin. In this regard, one can speak of the integrity and structure of the spatial organization of the sacred landscape, since it contains natural and cultural elements.

The investigated sacred landscapes are characterized by variability and genetic differentiation. Such territorial systems are not formed in isolated space, but in the structure of already existing natural, natural-man-made or anthropogenic landscapes, the spatial organization of which is determined by their properties and the nature of internal communications. Accordingly, the structure of natural landscapes is a combination of the most stable links between the constituent parts of the system, which were formed in 
the process of evolution.

The structure of the natural-human-made landscape is determined by a set of the most stable anthropogenically modified connections between the structural components of the system and individual anthropogenic elements.

Landscapes of anthropogenic origin are characterized by a structure determined by a set of relatively stable and unstable anthropogenically controlled and anthropogenically modified connections between the structural components of the anthropogenic system, which were formed in the process of qualitative transformation of natural and natural anthropogenic landscapes (Petlin, 2009). The functioning of sacred landscapes is ensured by the continuous transformation of matter, energy, information within the system, as well as between different systems. Such processes point to the existence of material-energy, information and interconnection links.

The sacral landscape is characterized by polystructure, that is, the presence of spatial, temporal, morphological structure on figure 1.

The spatial structure of the investigated territorial systems is characterized by spatial correlation and consistency of internal parts. Such a structure has anthropogenic origin. However, within a single sacred landscape there may be several religious (holy) objects. For example, within the limits of temple and monastic complexes, several sacred objects are typically recorded, in particular: the church itself, a burial place, a sacred spring in the courtyard of the church. The unifying characteristic of such objects is their spiritual perception by man. Such polyobjectivity is characterized by a hierarchy and determines the integrity of the sacred landscape. With the development of society, the sacred value of the holy object is changing. This is due to the logical changes in ideology, culture, and religious inquiry, which results in changes not only in the landscape itself, but also in its function, and therefore the structural organization.

The landscape structure consists of an eminently integral interaction of differentiated systemic entities formed as a result of the regular development of territorial unities. Within it, it is possible to distinguish between abiotic natural components that cover the hydrogeological, geomorphological, microclimatic features of the sacred landscape, as well as the flora and fauna that formed within it.

The anthropo-technogenic component is determined by a certain infrastructural maintenance

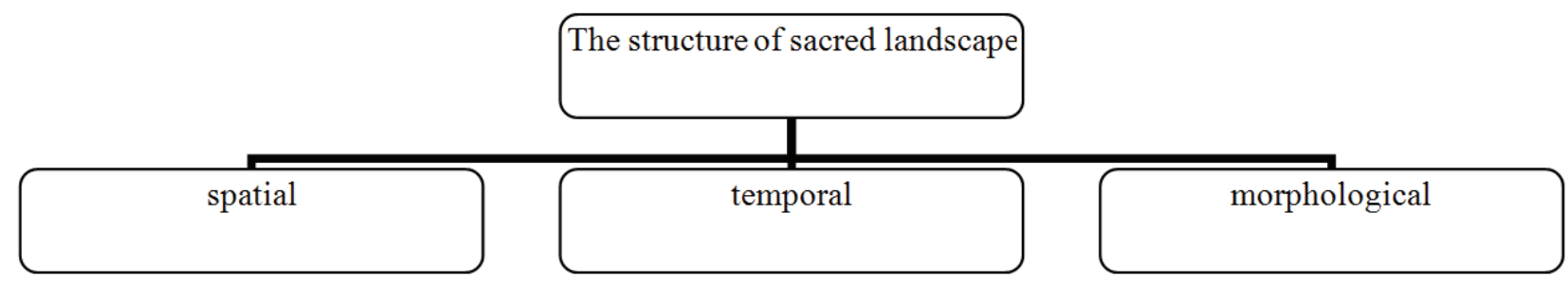

Fig. 1. Structures of the sacred landscape

signs of systemicity, orderliness, and interconnections. Within the spatial structure of the sacred landscape, one can distinguish the following components: a sacral object, an anthropogenic and man-made component, a landscape structure, a spiritual component, a person, as shown in Figure 2.

Any sacralization is related to the search for the centre, therefore the spatial structure of the sacred landscape, more often has the form of a monocentric system, which consists of a number of subsystems that are closely interconnected.

The central component of the spatial structure of a sacred landscape is the sacred object, which has a great sacred, cultural, curative, aesthetic, ideological significance for a certain group of people. Such an object can have a natural, natural-anthropogenic, of sacred landscapes, in particular: asphalt covering, church shops, etc.

Man perceives the sacred landscape not as an object for satisfaction of economic needs, but as an object that needs to be worshiped, honoured, and guarded. Instruments of sacralization of such objects are: religious feelings, legends, myths, symbols, historical facts, individual sacred feelings.

The spatial structure of the sacred landscape has a hierarchical structure, where individual, local, regional, national, global levels can be distinguished (Mishchenko, 2018). The existence of a hierarchy of sacral places is due to their differing degrees of attractive force. The larger the radius of attraction, the higher the hierarchical level is the sacred landscape (Hrodzynskyi, 2005). For example, for 


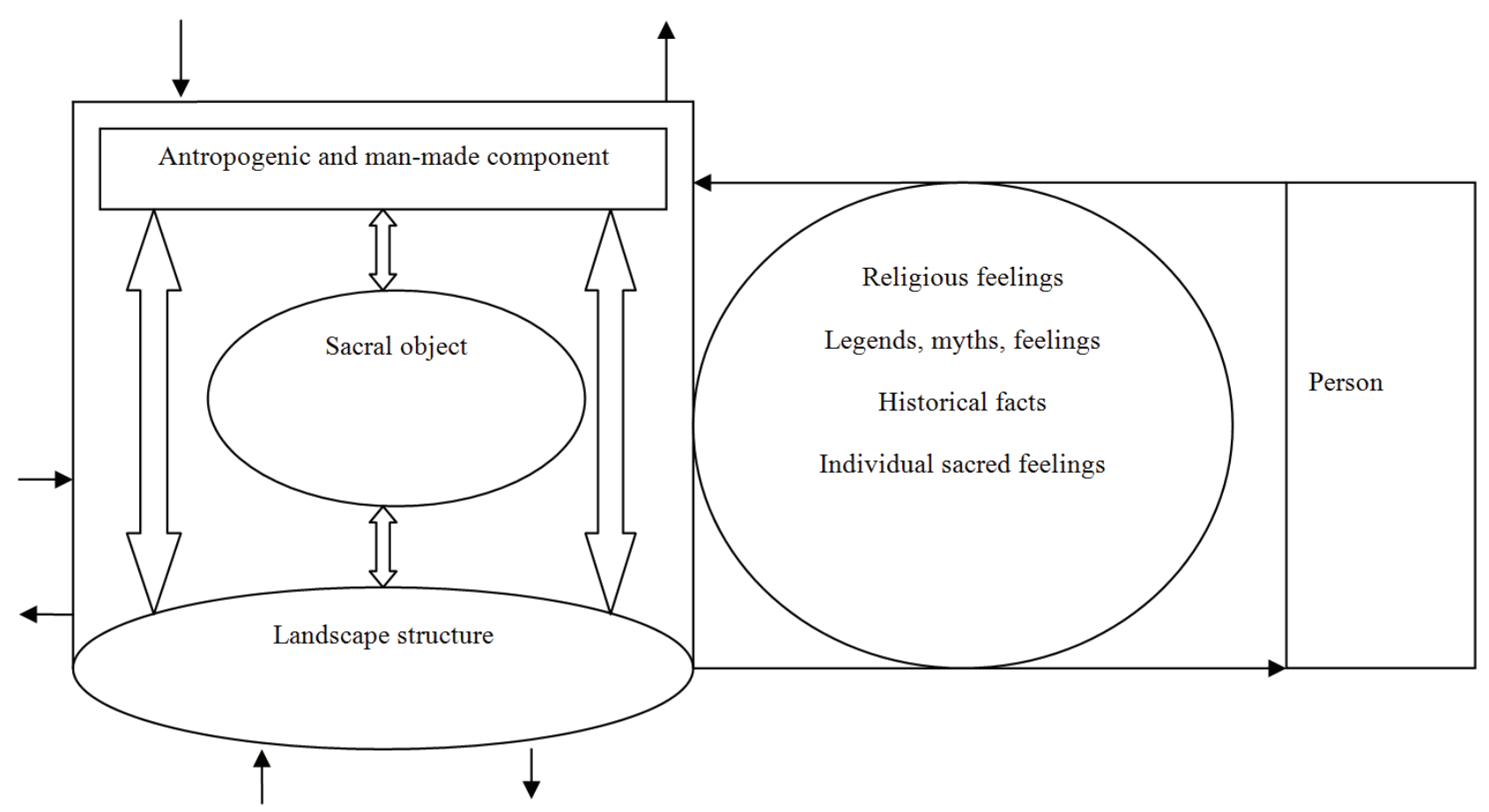

Fig. 2. Spatial structure of the sacred landscape NOTE antropogenic must be anthropogenic

all Christians, Jerusalem serves as the sanctuary of global significance. The radius of its attractive force encompasses the entire Christian world, because pilgrimage is made to this place from around the world. Undoubtedly, there are national sacred territories, in particular, Babyn Yar, a tract that is located in the northwestern suburbs of Kiev. This territory became known due to the mass executions, mainly of Jews, carried out during the German occupation in 1941-1943. An object of regional-level pilgrimage is a spring located in the catchment area of the Western Bug River and its right tributaries of the Luga River, near the village of Budyatychi, Ivanychi district, Volyn oblast. This spring became known for its curative properties in 1637. According to legend, the water of this spring healed people with various ailments. Now a well was built at this site, and a chapel next to it. People from different regions of Ukraine and from abroad come to the sacred spring. By contrast, the congregation of a village church has only to cover a small distance to reach their shared sacral object of local level. However, every person can have his own sacred landscape, which is formed by religious, ideological, cultural, aesthetic and other beliefs.

Time structure of the sacred landscape is determined by a certain change in the states of the system, which manifests itself in the form of seasonal rhythm and long-term restructuring of their relationships. The time structure of any landscape system is characterized by time duality, the content of which depends mainly on the specific features of a certain landscape system and the structural features of its background time (Petlin, 2009). The background time covers not only the existence time of the object (full time), but also the previous and future time. It characterizes the period of the emergence of the landscape's integrity, its development and destruction or transformation into a new integrity (Bokov, 2005). The definition of the background time of the landscape covers the characteristics of the features of its structure in certain periods of operation: the past, present and future.

The time in the landscape exists in three forms, in particular: external, internal and operating time (Bagrov et al., 2005).

The external time is characterized by the rhythm and cyclic nature of the physical and geographical processes occurring in the landscape. In general, time is determined by using different scales. At external time, the scale fixes the rhythmic natural processes that change the state of the landscape during the year or days. These processes are dynamic, and do not lead to the restructuring of the internal structure of the territorial system.

The internal time of the landscape is determined through a consistent, but not regular, arrhythmic change in its states. For the internal time of the territorial system, we can use the scale of the phases of its development. Landscape studies use the scale 
of states according to the age of the landscape, or its components, in particular: origin, youth, maturity, old age, death. Consequently, each phase has a different length of time. Considering this question, B. Polynov (1953) found that in each landscape there are different age elements: relict, conservative and progressive. Relict elements so old that tracts that are formed within them characterize the previous history of the landscape. To the category relict belong glacial relief forms, dry riverbeds. Conservative elements are in full compliance with modern natural conditions. Progressive elements indicate the ongoing trends of the landscape and reflect the possible changes. In the context of this issue, I. Mamaj (1982) proposes to distinguish three main phases of the development of landscapes: origin and formation; sustainable existence and slow development; atrophy. The development of the territorial system is conditioned by the gradual quantitative accumulation of elements of the new structure and displacement of the elements of the old structure, which in turn leads to qualitative changes within the landscape.

The internal time of sacred landscapes can be characterized by the following phases of development:

- formation of a natural, natural-anthropogenic, or anthropogenic landscape;

- creation of a spiritual component that determines the formation of the landscape's sacred value by people, that is, the sacred perception of the territorial system;

- loss of a person's sacred perception of a natural, natural-man-made or anthropogenic landscape, due to a change in ideology, political situation, culture, traditions, religious feelings;

- the disappearance of a natural, natural-manmade, anthropogenic landscape.

In landscape studies, it is extremely important to study not only its genesis and age but also spatial and functional relationships (Solncev, 1982). For a landscape, time does not pass until it is in a quasistable state. When transitioning to another state, the system is characterized by active functioning until it comes to a new quasi-stable state (Bagrov et al., 2005).

The sacred landscape is within the boundaries of the morphological structure of the landscape, that is, it is an integral part of the facies, tracts, terrain. Morphological structure of the landscape is such a correlation of components and the nature of the relationship between them which makes it possible to form interconnected hierarchical structures of the landscape (Petlin, 2018). The morphological structure is characterized by hierarchy, that is, functionally-ordered arrangement of structural parts of the geographical landscape from the lower to the higher, from the facies to the landscape terrain. Any morphological structure of the landscape due to the connections and corresponding functional processes of water exchange, mineral metabolism, gas exchange, energy exchange, biogenic circulation can develop and complicate. It should be taken into consideration that pure interactions within a single morphological pyramid do not exist, since each level interacts with the surrounding natural systems that belong to other neighbouring morphological levels of the hierarchy (Petlin, 2016).

Cult objects that serve as components and markers of sacred landscapes cannot fully correspond to one or another morphological unit of the landscape. For example, a chapel, a water source, separate burials can not be facies, or more than the morphological unit of the landscape, that is, fully corresponding to its contours and boundaries. Sacral objects are only components of one or another morphological unit of the natural, natural- anthropogenic, anthropogenic landscape. However, the pattern of structural organization of the morphological components of the territorial system, which is due to the interdependence between the type of landscape terrain and the peculiarities of the sacral object formed within it, is traced.

Consider the system of morphological structures of sacred landscapes on the example of the physical and geographical area of the Volyn Polissya shown in Figure 3.

According to the physical and geographical conditions within the Volyn Polissya, it is possible to distinguish the following types of landscaped terrain: floodplain and valleys of drainage, floodplain terraced, sloping, interfluve, plakor ( flat or gently sloping, well drained area). Almost all types of locality can be distinguished by the following types of sacred tracts: water areas, dendrological sites, temple and monastic complexes, funeral complexes.

Drainage of water areas has in its composition water sources, which are formed within the limits of the natural outlet of groundwater on the earth's surface where the aquifer crosses the earth's surface, that is, in the reliefs' depression, on the slopes of ravines, gulleys, etc. Water sources of the Volyn Polissya are most often formed in the river valleys, gullies, ravines, that is, fed by upper sources of flow due to the physical and geographical features of this territory. Often, such landscapes occur within floodplain areas, and in the structure of sacred landscapes are used not only to meet economic needs, but as objects that need to be worshiped, honoured and protected. 


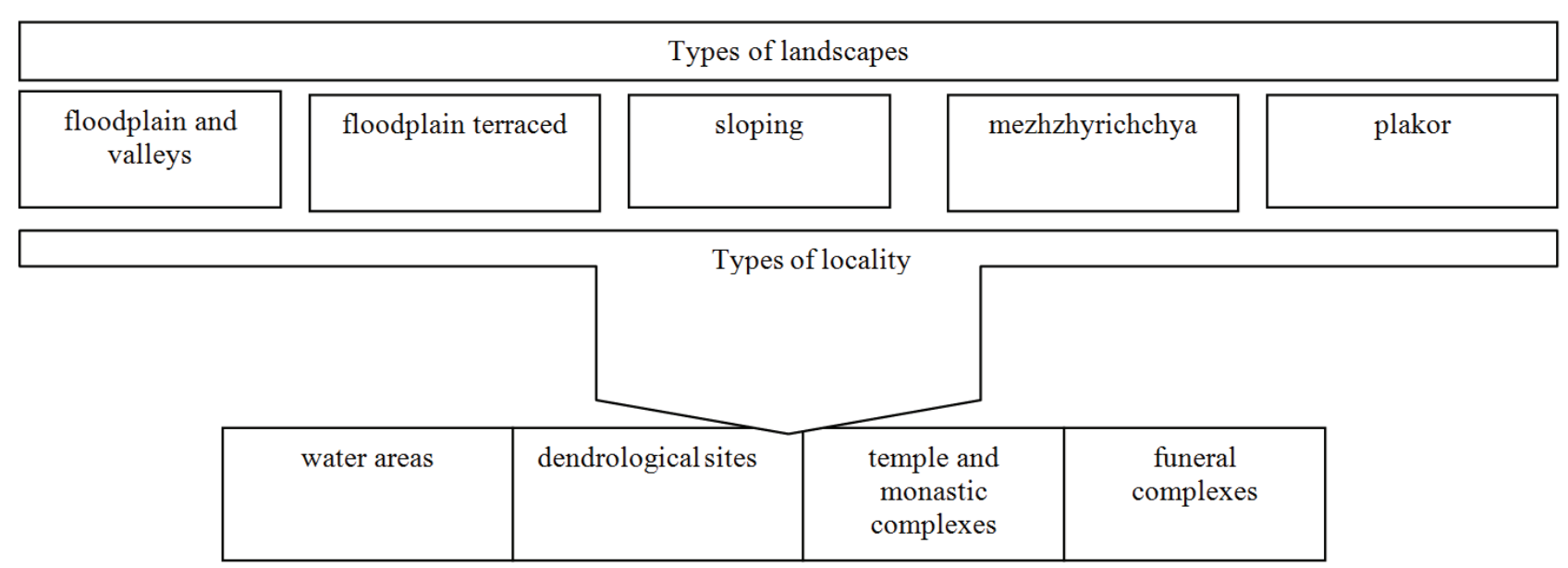

Fig. 3. System of morphological structures of sacred landscapes in conditions of Volyn Polissya. (Type of sacred tracts is determined by the nature of the sacred place)

The taphal landscapes represented by burial complexes can predominantly be formed within the plain and interfluve landscape, as the territory of such areas should not be subjected to landslides or landslips. In addition, geomorphological, geological, hydrogeological conditions and sanitary requirements do not contribute to the construction and formation of burial complexes in river floodplains.

The high hypsometric position of the temple and monastic complexes indicates their spiritual purpose and testifies to the supremacy of the sacred (Denysyk, 2014). Such complexes are mainly built on elevated areas, in particular in plakor, above floodplain terraces, interfluve types of landscape terrain.

Dendrological sites are represented by single trees, as well as sacred groves, can be formed in all of these types of landscaped terrain.

Consequently, there is a natural interdependence between the types of sacred tracts and the terrain in which they are formed. Such compatibility is conditioned by physical and geographical and aesthetic characteristics, environmental norms of the formation of a cult object, its social and functional purpose and confessional demands of society.

Conclusion. The studies of the structural organization of sacred landscapes testify that such territorial systems have in their structure a spiritual component that is connected with life symbols, myths, significant events, religious feelings. The tools of sacralization of the landscape are formed by the spiritual experience of a person, which in its essence is wider than the purely religious.

The social and functional purpose of a sacral landscape clearly forms its structure and organizational capabilities. This article describes the structures of sacred landscapes, in particular: spatial, temporal, morphological.
Within the spatial structure of the sacredlandscape, the following components are distinguished: the actual sacral object, the anthropogenic and man-made component, the landscape structure, the person with his/her spiritual experience.

This work describes the temporal forms of the sacred landscape. Particular attention is paid to the internal time, where the phases of development of the investigated territorial systems are distinguished.

Cult objects that serve as an inalienable attribute of sacred landscapes and ensure their integrity cannot fully correspond to one or another morphological unit of the landscape, that is, repeat their outlines and boundaries. However, there is a correlation between the type of landscape terrain and the features of sacred objects.

This research deals with the structural organization of sacred landscapes in general. However, depending on the functional purpose, the phase of development, other features of the organizational structure of the landscape will change. The study of the structural organization of taphal landscapes will be the goal of our further research.

\section{References}

Bagrov N. V., Bokov V. A., Chervanev I. G., 2005. Prostranstvenno-vremennye otnoshenija $\mathrm{V}$ samoorganizacii geosistem [Spatio-temporal relations in the self-organization of geosystems]. Geopolitics and ecogeodynamics of regions. Vol. 1, 12-20 (in Russian).

Bogdanov A. A., 1925. Vseobshhaja organizacionnaja nauka [General Organizational Science]. Kniga, Moscow-Leningrad (in Russian).

Bokov V. A., 2005. Prostranstvenno-vremennaja organizacija geosistem [Spatio-temporal organization of geosystems]. Simferopol State Univer- 
sity, Simferopol (in Russian).

Cushman S. A., Shirk A., Landguth E. L., 2012. Separating the effects of habitat area, fragmentation and matrix resistance on genetic differentiation in complex landscapes. Landscape Ecology. Vol. 27, 369-380.

Denysyk H. I., 2014. Antropohenne landshaftoznavstvo [Anthropogenic landscape studies]. Regional anthropogenic landscape science. Vol. 2. Vinnytsia Regional Printing House, Vinnytsia (in Ukrainian). .

Hrodzynskyi M. D., 2005. Piznannia landshaftu: mistse i prostir: monohrafiia [Understanding of the landscape: place and space: monograph]. Vol. 2. Kyiv National Taras Shevchenko University, Kyiv (in Ukrainian).

Ivanov Ye., 2007. Landshafty hirnychopromyslovykh terytorii [Landscapes of the mining industry]. Lviv Ivan Franko National University, Lviv (in Ukrainian).

Kizima V. V., 2003. Landshaftnaja sushhnost' Boga ili "Bozhestvennaja" priroda landshafta? [The landscape essence of God or the "Divine" nature of the landscape?]. Totallogy - XXI. Postneoclassical research. NAS of Ukraine, Kyiv. 10, 8-53 (in Russian).

Lavrinova N. N., 2015. Model vzaimodeystviya geograficheskogo, kulturnogo i sakralnogo landshaftov [Model of interaction of geographical, cultural and sacred landscapes]. Vestn. Tambov. Univ. Ser. Philology and Cultural Studies. 2 (2), 44-51 (in Russian).

Leskov L. V., 2005. Futurosinergetika: universal'naja teorija sistem [Futurosynergy: universal systems theory]. Ekonomika, Moscow (in Russian).

Mazing V. V., 1973. CHto takoe struktura biogeotsenoza [What is the structure of biogeocenosis]. Problems of biogeocenology. Nauka, Moscow, 148-156 (in Russian).

Mamaj I. I., 1982. Sostojanie prirodnyh territorial'nyh kompleksov [The state of natural territorial complexes]. Geography issues. 121, 22-38 (in Russian).

Mil'ner B. Z., 2005. Teorija organizacii [Organization Theory]. Infra-M, Moscow (in Russian).

Mishchenko O. V., 2018. Sakralnyi landshaft: zmist ta funktsii [Sacred Landscape: contents and functions]. Visn. Kyiv. Univ. Ser. Geography. 1 (70), 8388. doi.org/10.17721/1728-2721.2018.70.15 (in Ukrainian).

Nechiporenko V. I., 1977. Strukturnyj analiz sistem (jeffektivnost' i nadezhnost') [Structural analysis of systems (efficiency and reliability)]. Sov. Radio, Moscow (in Russian).

Papadimitriou F., 2010. Geo-mathematical modelling of spatial-ecological complex systems: an evalu- ation. Geography, Environment, Sustainability. Vol. 3. (1), 67-80.

Petlin V. M., 2006. Konstruktyvne landshaftoznavstvo [Constructive landscape science]. Publishing Center Lviv Ivan Franko National University, Lviv (in Ukrainian).

Petlin V. M., 2009. Metodolohiia ta metodyka eksperymentalnykh landshaftoznavchykh doslidzhen. [Methodology and methodology of experimental landscapes research]. Publishing Center Lviv Ivan Franko National University, Lviv (in Ukrainian).

Petlin V. M., 2016 Teoriia pryrodnykh terytorialnykh system [The theory of natural territorial systems]. Vol. 2. Natural territorial systems: concepts, paradigms, organization. Publishing Center Lviv Ivan Franko National University, Lviv (in Ukrainian).

Petlin V. M., 2018. Teoriia pryrodnykh terytorialnykh system [Hierarchy of natural territorial systems]. PrAT Volynska oblasna drukarnia, Lutsk (in Ukrainian).

Polynov B. B., 1953. Uchenie o landshaftah [The doctrine of landscapes]. Geography issues. 33, 30-44. (in Russian).

Preobrazhenskij V. S., 1986. Organizacija, organizovannost' landshafta [Organization, landscape organization]. Institute of Geography, Academy of Sciences of the USSR, Moscow (in Russian).

Sadovskij V. N., 1974. Osnovanija obshhej teorii sistem [Foundations of the general theory of systems]. Nauka, Moscow (in Russian).

Samoilenko V. M., 2003. Matematychne modeliuvannia $\mathrm{v}$ heoekolohii [Mathematical modeling in geoecology]. Publishing and Printing Center Kyiv University, Kiev (in Ukrainian).

Solncev V. N., 1982. Sistemnaja organizacija landshaftov [Landscape Systems Organization]. Mysl', Moscow (in Russian).

Topchiev A. G., 1988. Prostranstvennaja organizacija geograficheskih kompleksov i sistem [Spatial organization of geographic complexes and systems]. Vyshcha shkola, Kiev-Odessa (in Russian).

Turner M., Gardner R. H., O`Neill R.V., 2001. Landscape Ecology in Theory and Practice: Pattern and Process. Springer Verlag.

Velykyi tlumachnyi slovnyk suchasnoi ukrainskoi movy, 2005 [Great explanatory dictionary of modern Ukrainian language]. Perun, Kiev-Irpin (in Ukrainian).

Volovyk V. M., 2013. Etnokulturni landshafty: rehionalni struktury i pryrodokorystuvannia [Ethnocultural landscapes: regional structures and nature]. Vinnitsa City Printing House, Vinnitsa (in Ukrainian). 